\title{
Barn i blindsonen
}

I møte med en som opplever sykdom, ulykker eller kriser kan det være lett å glemme at pasienten ofte har familie som også blir berørt. Mens helsetjenesten de siste årene har opparbeidet gode rutiner for å ivareta foreldre som pårørende, har barn som pårørende lenge vært en ganske usynlig gruppe. Det er derfor gledelig at Norsk elektronisk legehåndbok nylig er blitt oppdatert med kapitlet Barn som pårørende.

Årlig opplever nesten 3500 barn at en av foreldrene får kreft og 6 000-9 000 at mor eller far kommer i fengsel, og 70000 barn har foreldre med alkoholproblemer som går utover daglig fungering (1). Slike belastninger fører ofte til store og langvarige endringer i familiesituasjonen. Samfunnet er i stadig endring og beveger seg i mer multikulturell retning, med større mangfold i familiemønstre enn tidligere. Samtidig er det et økende antall skilsmisser, og det blir flere enslige foreldre. For noen medfører dette også svakere nettverk. Dette er forhold som gjør det vanskelig å vite hvilke behov en familie har i en situasjon der foreldrene blir rammet av alvorlige helseproblemer. Generelt kan vi si at barn er en spesielt utsatt og sårbar gruppe som kan komme til å trenge ekstra støtte i en slik situasjon.

Selv om de fleste foreldre vil det beste for sine barn, kan det være vanskelig å gi den omsorg som barnet trenger når man selv sliter. Barn er sensitive for hvordan foreldrene har det og kan lett gå inn i en omsorgsrolle. Alderstilpassede omsorgsoppgaver kan innebære mestring og utvikling, mens et for stort og overveldende ansvar kan være belastende og skadelig. Hjelptrengende foreldre kan over tid miste «normalsynet» på hva som er barns oppgaver og ansvar, samtidig som skam og skyldfølelse kan bidra til at foreldrenes sykdom forblir en vel bevart familiehemmelighet. Det kan være en tung bør å bære for familien - særlig barna - og det kan pågå over lang tid (2).

\section{Belastende livserfaringer i barndommen}

Barn som lider overlast på grunn av overveldende omsorgsbyrder eller omsorgssvikt, har økt risiko for å få helseproblemer selv, både på kort og på lang sikt (3-5). Senere års forskning har bidratt til en langt dypere forståelse av grunnleggende sammenhenger mellom livsbetingelser og helse. Det er nå godt kjent at belastninger i fosterliv og tidlig barndom kan innvirke på helsetilstanden senere i livet, for eksempel i form av sykdom i voksen alder $(4,6,7)$.

Noen utviklingsfaser er spesielt kritiske. For eksempel er vår evne til å knytte oss til andre mennesker særlig sensitiv de første par leveårene $(8,9)$. Samtidig har vi nå kunnskap om at hjernen til små barn er langt mer plastisk enn det man tidligere trodde $(9,10)$. Det er altså et stort potensial for reparasjon hvis barn har vært utsatt for overlast/omsorgssvikt - samtidig som det understreker betydningen av å gripe inn tidlig nok.

\section{Lovbestemmelser \\ om barn som pårørende}

For å bedre oppfølgingen av barn som pårørende opprettet Helse - og omsorgsdepartementet i 2007 BarnsBeste - et nasjonalt kompetansenettverk for barn som pårørende (11). 1.1. 2010 fikk helsepersonelloven og spesialisthelsetjenesteloven bestemmelser som har som formål å bidra til at disse barna blir ivaretatt og får nødvendig støtte $(12,13)$.

Helsepersonell har etter loven plikt til å avklare om pasienten har barn, foreta en kartlegging av barnas behov for informasjon og oppfølging samt iverksette tiltak

\section{«Alvorlig omsorgssvikt forekommer oftere enn vi liker å tro»}

der det er nødvendig. Som ledd i arbeidet med å systematisere og formidle kunnskap om barn som pårørende har BarnsBeste i samarbeid med fagfolk utarbeidet et eget kapittel om dette temaet i Norsk elektronisk legehåndbok (1). Målet er å nå fastlegene. Mulighetene skulle være gode, ettersom flesteparten av landets fastleger har tilgang til Norsk elektronisk legehåndbok.

\section{Grønn - gul - rød respons}

Det er viktig å fremheve at barn som har syke foreldre i utgangspunktet er friske barn, og at deres atferd ofte representerer en normal reaksjon på en unormal situasjon. Det er viktig å vurdere atferdsendring hos barn ut fra den kontekst barnet befinner seg i. Barns reaksjon på en belastende livssituasjon kan være svært varierende. Noen reagerer med å bli tilbaketrukne og «usynlige», andre med sinne og utagering.

Barn som utsettes for omsorgssvikt, kan ha symptomer som fyller kriterier for diagnoser som $\mathrm{AD} / \mathrm{HD}$ og andre atferdsforstyrrelser. Faren er at «diagnosen» blir en forklaring som alle symptomer tolkes inn i. Resultatet kan være at traumer og omsorgssvikt blir oversett (14).
Fastlegen kan følge familien over tid, noe som gir gode muligheter til å vurdere barn i den konteksten de befinner seg i. Norsk elektronisk legehåndbok beskriver fastlegens ulike responsmuligheter etter trafikklysmetoden. Hvis barna er godt i varetatt og omsorgspersonene samarbeider godt, er det ingen grunn for videre tiltak (grønn respons). Hvis barn står i fare for å lide overlast og omsorgspersonene ikke har innsikt i situasjonen og/eller ikke ønsker hjelp, har helsepersonell plikt til å melde fra til barnevernet (rød respons). Ved tvil skal man undersøke nærmere, vurdere barnas situasjon og eventuelt konferere med andre aktører (gul respons).

\section{Respektfull tilnærming}

Det er ikke lett å være barn når foreldrene blir syke - men heller ikke lett å være foreldre når man er syk. Dårlig samvittighet for ikke å strekke til som foreldre er vanlig selv når man er frisk. Det er mange meninger om hvordan foreldre skal være og hva barn trenger. Her ligger det en utfordring for helsepersonell: Hvordan kan vi på en respektfull måte få syke foreldre til å bli oppmerksomme på hvordan deres barn har det når de selv sliter og er sårbare? Hvilke reaksjoner bør foreldre og omverdenen være på vakt overfor?

Hvordan kan man best ivare ta og støtte hele familien - inkludert barn og den friske andre forelderen? Samtidig som vi må ta innover oss den smertefulle erkjennelsen at alvorlig omsorgssvikt forekommer oftere enn vi liker å tro, og mobilisere kraft og mot til å handle der vi har grunn til å tro at barn utsettes for slikt.

\section{Bente Prytz Mjølstad}

bente.mjolstad@ntnu.no

Bente Prytz Mjølstad (f. 1972) er allmennlege og stipendiat ved Allmennmedisinsk forskningsenhet, Institutt for samfunnsmedisin, Norges teknisk-naturvitenskapelige universitet. Hun underviser på lege-pasient-kurset ved universitetet og er medlem i styret for Norsk forening for allmennmedisin. Hun er en av flere fagmedarbeidere som har gitt råd til forfatterne om utformingen av kapitlet Barn som pårørende i Norsk elektronisk legehåndbok.

Forfatter har fylt ut ICMJE-skjemaet og oppgir ingen interessekonflikter. 


\section{Litteratur}

1. Thorsen E, Romedal S, Raknes S et al. Barn som pårørende. Norsk Elektronisk Legehåndbok. http://legehandboka.no/generelt/symptomer-ogtegn/pasientens-barn-barn-som-parorende39310.html. (26.5.2013).

2. Breivik A. Tid for familien - når barn er pårørende. Sluttrapport fra utviklingsprosjekt. Rapport nr. 1/2011. Valnesfjord, Fauske: Valnesfjord Helsesportsenter, 2011.

3. Felitti VJ, Anda RF. The relationship of adverse childhood experiences to adult medical disease, psychiatric disorders and sexual behavior: implications for healthcare. I: Lanius RA, Vermetten E. Pain C, red. The impact of early life trauma on health and disease. The hidden epidemic. Cambridge: Cambridge University Press, 2010.

4. Danese A, McEwen BS. Adverse childhood experiences, allostasis, allostatic load, and age-related disease. Physiol Behav 2012; 106: 29-39.

5. Kirkengen AL. Hvordan krenkede barn blir syke voksne. Oslo: Universitetsforlaget, 2009.

6. Shonkoff JP, Boyce WT, McEwen BS. Neuroscience, molecular biology, and the childhood roots of health disparities: building a new framework for health promotion and disease prevention. JAMA 2009; 301: 2252-9.

7. McEwen BS, Getz L. Lifetime experiences, the brain and personalized medicine: an integrative perspective. Metabolism 2013; 62 (suppl 1): S20-6

8. Bowlby J. A secure base: parent-child attachment and healthy human development. London: Routledge, 1988

9. Science of early childhood-Center on the developing child - Harvard University. http://developingchild.harvard.edu/topics/ science of early childhood/ (27.5.2013).

10. Karatoreos IN, McEwen BS. Annual Research Review: The neurobiology and physiology of resilience and adaptation across the life course. J Child Psychol Psychiatry 2013; 54: 337-47

11. BarnsBeste. www.sorlandet-sykehus.no/pasient/ kompetansentre/barnsbeste/Sider/side.aspx (26.5.2013).

12. Lov om helsepersonell mv. (helsepersonelloven). § 10a, \& 25. LOV-1999-07-02-64.

13. Lov om spesialisthelsetjenesten m.m. (spesialisthelsetjenesteloven). § 3-7a. LOV-1999-07-02-61.

14. Kirkengen AL, Thornquist E. Når diagnoser gjør blind. Tidsskr Nor Legeforen 2013; 133: 1466-8.

Mottatt 21.5. 2013 og godkjent 24.5. 2013. Medisinsk redaktør Hanne Støre Valeur.

Engelsk oversettelse på www.tidsskriftet.no

Publisert først på nett. 